\title{
Effect of Temperature on the Complexation of
}

\section{Uranium(VI) with Fluoride in Aqueous Solutions}

\author{
Guoxin Tian and Linfeng Rao* \\ Lawrence Berkeley National Laboratory, Berkeley, CA 94720, U.S.A.
}

LRao@lbl.gov

Temperature effect on the complexation of U(VI) with fluoride

ABSTRACT. Complexation of U(VI) with fluoride at elevated temperatures in aqueous solutions was studied by spectrophotometry. Four successive complexes, $\mathrm{UO}_{2} \mathrm{~F}^{+}, \mathrm{UO}_{2} \mathrm{~F}_{2}(\mathrm{aq}), \mathrm{UO}_{2} \mathrm{~F}_{3}^{-}$and $\mathrm{UO}_{2} \mathrm{~F}_{4}{ }^{2-}$, were identified and the stability constants at $25,40,55$ and $70^{\circ} \mathrm{C}$ were calculated. The stability of the complexes increased as the temperature was elevated. The enthalpies of complexation at $25^{\circ} \mathrm{C}$ were determined by microcalorimetry. Thermodynamic parameters indicate that the complexation of $\mathrm{U}(\mathrm{VI})$ with fluoride in aqueous solutions at 25 to $70^{\circ} \mathrm{C}$ is slightly endothermic and entropy-driven. The Specific Ion Interaction (SIT) approach was used to obtain the thermodynamic parameters of complexation at infinite dilution. Structural information on the $\mathrm{U}(\mathrm{VI}) /$ fluoride complexes was obtained by EXAFS spectroscopy.

KEY WORDS. Uranium, fluoride, complexation, temperature effect

\section{INTRODUCTION}


One of the strategies for the safe management of nuclear wastes is to store the high-level nuclear wastes (HLW) in underground geological repositories. Due to the high radiation energy released from the HLW, the postclosure repository is expected to remain at elevated temperatures for thousands of years [1]. If the waste package is breached and becomes in contact with groundwater, the radioactive materials in the HLW will be in aqueous solutions at elevated temperatures. As a result, the interactions of radionuclides with the chemical components in the groundwater at elevated temperatures could determine the migration behavior of radionuclides in the repository.

According to the radionuclide inventory for the HLW to be disposed of in the underground repository, uranium is the most abundant radionuclide in the waste forms (including commercial and DOE spent nuclear fuels and the HLW glass logs) [1]. Under oxidizing conditions, uranium is most likely to be in the hexavalent state. Therefore, the migration of $\mathrm{U}(\mathrm{VI})$ in the postclosure environment of the repository is a great concern to long-term repository performance. To predict the migration behavior of uranium, it is necessary to have sufficient and reliable thermodynamic data on its complexation with the ligands (e.g., $\mathrm{OH}^{-}, \mathrm{F}^{-}, \mathrm{SO}_{4}{ }^{2-}, \mathrm{PO}_{4}{ }^{3-}$ and $\mathrm{CO}_{3}{ }^{2}$ ) that are present in the groundwater of the repository at elevated temperatures. Among the ligands, fluoride $\left(\mathrm{F}^{-}\right)$is known to form fairly strong complexes with U(VI) at or near $25^{\circ} \mathrm{C}$ so that complexation of $\mathrm{U}(\mathrm{VI})$ with fluoride could play a significant role in determining the speciation and migration behavior of $\mathrm{U}(\mathrm{VI})$ in the repository. There are about 20 papers in the literature where the stability constants of U(VI)/fluoride complexes at or near $20-25^{\circ} \mathrm{C}$ are reported $[2,3]$. In contrast, few data on the complexation of $\mathrm{U}(\mathrm{VI})$ with fluoride at elevated temperatures are available and there is only one study where the enthalpy of complexation was determined by calorimetry [4]. There are a few studies in which luminescence properties (e.g., lifetime) of the U(VI)/fluoride system at variable temperatures were observed, but no stability constants were measured $[5,6]$. The lack of stability constants at elevated temperatures and the scarcity of enthalpy data make it difficult to predict the migration behavior of $\mathrm{U}(\mathrm{VI})$ in the repository at elevated temperatures. To provide reliable thermodynamic data on the complexation of U(VI) with fluoride at elevated temperatures, we have studied the complexation of U(VI) with fluoride at variable temperatures. 
Stability constants of $\mathrm{U}(\mathrm{VI}) /$ fluoride complexes at $25,40,55$ and $70^{\circ} \mathrm{C}$ were determined by spectrophotometry and the enthalpy of complexation at $25^{\circ} \mathrm{C}$ was determined by microcalorimetry. Extended X-ray Absorption Fine Structure (EXAFS) spectroscopy was used to obtain structural information on the U(VI)/fluoride complexes in aqueous solution.

\section{EXPERIMENTAL}

\subsection{Chemicals}

All chemicals except uranium were reagent grade or higher. Water from a Milli-Q system was used in preparing all solutions. Details on the preparation and standardization of the U(VI) stock solution were provided elsewhere [7]. Gran's potentiometric method [8] was used to determine the concentration of free acid in the U(VI) stock solution. Solutions of fluoride were prepared by dissolving solid NaF in water. The ionic strength of all working solutions in this study was maintained at $1.0 \mathrm{~mol} \cdot \mathrm{dm}^{-3}\left(25^{\circ} \mathrm{C}\right)$ by adding appropriate amounts of sodium perchlorate as the background electrolyte.

\subsection{Spectrophotometry}

UV/Vis absorption spectra of U(VI) (380 - $480 \mathrm{~nm}, 0.2 \mathrm{~nm}$ interval) were collected on a Varian Cary5G spectrophotometer equipped with sample holders that were maintained at constant temperatures by a Peltier controller. $10 \mathrm{~mm}$ quartz cuvettes were used. Before being inserted into the sample holders, the sealed cuvettes were immersed in an external constant-temperature water bath for $30-40$ minutes to be pre-equilibrated at the required temperature. This procedure successfully prevented condensation of water on the top of the cuvettes during the spectrophotometric measurements at high temperatures. The sample holders are also equipped with magnetic stirrers so that thorough mixing of the titrant was achieved while the cuvettes were sealed to minimize water evaporation during the titration. Multiple titrations with different concentrations of U(VI) and acid were performed. In each titration, appropriate aliquots of the titrant $\left(0.900 \mathrm{~mol} \cdot \mathrm{dm}^{-3} \mathrm{NaF} / 0.100 \mathrm{~mol} \cdot \mathrm{dm}^{-3} \mathrm{HF}\right)$ were added into the cuvette and mixed thoroughly before the absorption spectrum was collected. Usually 25 - 30 additions were made, thus generating a set of 25 - 30 spectra in each titration. The stability constants of the U(VI)/fluoride 
complexes (on the molarity scale) were calculated by non-linear least-square regression using the Hyperquad program [9].

\subsection{Microcalorimetry}

The enthalpies of complexation of $\mathrm{U}(\mathrm{VI})$ with fluoride at $25^{\circ} \mathrm{C}$ were determined by microcalorimetric titrations conducted on an isothermal microcalorimeter (Model ITC 4200, Calorimetry Science Corp.). The performance of the calorimeter has been tested by measuring the enthalpy of protonation of tris(hydroxymethyl)-aminomethane (THAM). The result was $-(47.7 \pm 0.2) \mathrm{kJ}^{\mathrm{mol}} \mathrm{mol}^{-1}$ at $25^{\circ} \mathrm{C}$, in excellent agreement with the value in the literature. Details of the microcalorimeter are provided elsewhere [10].

In the titrations of the complexation of U(VI) with fluoride, a U(VI) solution of $0.90 \mathrm{~cm}^{3}$ (at $25^{\circ} \mathrm{C}$ ) was placed in the titration vessel and titrated with a solution of $0.300 \mathrm{~mol} \cdot \mathrm{dm}^{-3} \mathrm{NaF} / 0.0333 \mathrm{~mol} \cdot \mathrm{dm}^{-3} \mathrm{HF}$ in increments of $5 \mu \mathrm{l}$. Multiple titrations were conducted at each temperature. For each titration, $n$ additions were made (usually $n=40-50$ ), resulting in $n$ experimental values of the heat generated in the reaction cell $\left(Q_{\mathrm{ex}, \mathrm{j}}\right.$, where $j=1$ to $\left.n\right)$. These values were corrected for the heat of dilution of the titrant $\left(Q_{\mathrm{dil}, \mathrm{j}}\right)$, which was determined in separate runs. The net reaction heat at the $j$-th point $\left(Q_{\mathrm{r}, \mathrm{j}}\right)$ was obtained from the difference: $Q_{\mathrm{r}, \mathrm{j}}=Q_{\mathrm{ex}, \mathrm{j}}-Q_{\mathrm{dil}, \mathrm{j}}$. multiple titrations were conducted using solutions of different concentrations of U(VI) and acid. The program Letagrop [11] was used to analyze the data and calculate the thermodynamic parameters.

2.4 Extended X-ray absorption fine structure spectroscopy (EXAFS).

Uranium $\mathrm{L}_{\mathrm{III}}$-edge EXAFS spectra of five solution samples were collected at $\mathrm{t}=22^{\circ} \mathrm{C}$ at the Stanford Synchrotron Radiation Laboratory (SSRL) on wiggler beam line 11-2. The conditions of the samples were such that the dominant $\mathrm{U}(\mathrm{VI})$ species in the solutions are $\mathrm{UO}_{2}{ }^{2+}, \mathrm{UO}_{2} \mathrm{~F}^{+}, \mathrm{UO}_{2} \mathrm{~F}_{2}(\mathrm{aq}), \mathrm{UO}_{2} \mathrm{~F}_{3}{ }^{-}$and $\mathrm{UO}_{2} \mathrm{~F}_{4}{ }^{2-}$, respectively. Approximately $1 \mathrm{~mL}$ of the solution was sealed in a polyethylene tube $(5 \mathrm{~mm}$ i.d.). The polyethylene tubes were mounted on an aluminum sample positioner with Scotch tape for the experiments. Data were collected up to $k_{\max } \sim 16 \AA^{-1}$ in both transmission and fluorescence modes. Three to six scans were performed for each sample. Energy calibrations were based on assigning the 
first inflection point of absorption edge for uranium dioxide to $17166 \mathrm{eV}$. The EXAFS data were analyzed with the program WinXAS Version 3.1 [12], using parameterized phase and amplitude functions generated by FEFF8 [13] with the crystal structure of bis(tetramethylammonium) aquotetrafluorodioxouranate (VI) dihydrate [14]. Single scattering interactions of $\mathrm{U}=\mathrm{O}_{\text {axial }}$ (axial oxygen), U-O $\mathrm{O}_{\text {eq }}$ (equatorial oxygen) and $\mathrm{U}-\mathrm{F}$ were included.

\section{RESULTS AND DISCUSSION}

3.1 Stability constants of $\mathrm{U}(\mathrm{VI}) /$ fluoride complexes at elevated temperatures

Figure 1 shows the absorption spectra of two representative spectrophotometric titrations at 25 and $70^{\circ} \mathrm{C}$. As the titrant was added, the position and intensity of the absorption bands changed. The changes can be discussed in two phases. In the first phase of the titration (two upper figures), the absorption bands were red-shifted and the intensity increased as the concentration of fluoride was increased. In contrast, in the second phase of the titration (two lower figures), little change in the position of the absorption bands occurred and the intensity decreased as the fluoride concentration was increased. The spectra of the titrations at 40 and $55^{\circ} \mathrm{C}$ are not shown, but similar changes in the position and intensity of the absorption bands are observed during the titrations.

\section{(insert Figure 1)}

Factor analysis of the absorption spectra with the Hyperquad program indicated that there were five absorbing species of $\mathrm{U}(\mathrm{VI})$ and the spectra were best-fitted with successive formation of four $\mathrm{U}(\mathrm{VI})$ /fluoride complexes $\left(\mathrm{UO}_{2} \mathrm{~F}^{+}, \mathrm{UO}_{2} \mathrm{~F}_{2}(\mathrm{aq}), \mathrm{UO}_{2} \mathrm{~F}_{3}^{-}\right.$, and $\left.\mathrm{UO}_{2} \mathrm{~F}_{4}{ }^{2-}\right)$, represented by equations 1-4.

$$
\begin{aligned}
& \mathrm{UO}_{2}{ }^{2+}+\mathrm{F}^{-}=\mathrm{UO}_{2} \mathrm{~F}^{+} \\
& \mathrm{UO}_{2}{ }^{2+}+2 \mathrm{~F}^{-}=\mathrm{UO}_{2} \mathrm{~F}_{2}(\mathrm{aq}) \\
& \mathrm{UO}_{2}{ }^{2+}+3 \mathrm{~F}^{-}=\mathrm{UO}_{2} \mathrm{~F}_{3}^{-} \\
& \mathrm{UO}_{2}{ }^{2+}+4 \mathrm{~F}^{-}=\mathrm{UO}_{2} \mathrm{~F}_{4}{ }^{2-}
\end{aligned}
$$


The molar absorptivities of $\mathrm{UO}_{2}{ }^{2+}$ and the four complexes at $25,40,55$ and $70^{\circ} \mathrm{C}$ are calculated by the Hyperquad program, though only those at 25 and $70^{\circ} \mathrm{C}$ are shown in Figure 2. To compare the spectra features at different temperatures, the wavelength of maximum absorption $\left(\lambda_{\max }\right)$ and the molar absorptivity at the wavelength $\left(\varepsilon_{\max }\right)$ are plotted for all $\mathrm{U}(\mathrm{VI})$ species $25,40,55$ and $70^{\circ} \mathrm{C}$ in Figure 3. Two trends are observed: (1) For all U(VI) species, $\lambda_{\max }\left(25^{\circ} \mathrm{C}\right)<\lambda_{\max }\left(40^{\circ} \mathrm{C}\right)<\lambda_{\max }\left(55^{\circ} \mathrm{C}\right)<\lambda_{\max }$ $\left(70^{\circ} \mathrm{C}\right)$, and $\varepsilon_{\max }\left(25^{\circ} \mathrm{C}\right)<\varepsilon_{\max }\left(40^{\circ} \mathrm{C}\right)<\varepsilon_{\max }\left(55^{\circ} \mathrm{C}\right)<\varepsilon_{\max }\left(70^{\circ} \mathrm{C}\right)$. In other words, the absorption bands are red-shifted and intensified as the temperature is increased. The shift in the wavelength and the increase in the intensity are generally larger for the U(VI)/fluoride complexes (except for the $\lambda_{\max }$ of $\mathrm{UO}_{2} \mathrm{~F}_{4}{ }^{2-}$ ) than those for the free $\mathrm{UO}_{2}{ }^{2+}$ ion (Figure 3). Such observations, also obtained for several other $\mathrm{U}(\mathrm{VI})$ complexation systems $[15,16,17]$, imply that the complexation of U(VI) by fluoride is enhanced at elevated temperatures. (2) At each temperature, the $\lambda_{\max }$ and $\varepsilon_{\max }$ do not increase monotonously from the free $\mathrm{UO}_{2}{ }^{2+}$ ion to successively higher complexes $\left(\mathrm{UO}_{2} \mathrm{~F}^{+}, \mathrm{UO}_{2} \mathrm{~F}_{2}(\mathrm{aq}), \mathrm{UO}_{2} \mathrm{~F}_{3}{ }^{-}\right.$, and $\left.\mathrm{UO}_{2} \mathrm{~F}_{4}{ }^{2-}\right)$. In fact, $\lambda_{\max }\left(\mathrm{UO}_{2} \mathrm{~F}_{4}{ }^{2-}\right)<\lambda_{\max }\left(\mathrm{UO}_{2} \mathrm{~F}_{3}{ }^{-}\right)$, and $\varepsilon_{\max }\left(\mathrm{UO}_{2} \mathrm{~F}_{4}{ }^{2-}\right)<\varepsilon_{\max }\left(\mathrm{UO}_{2} \mathrm{~F}_{3}{ }^{-}\right)<\varepsilon_{\max }\left(\mathrm{UO}_{2} \mathrm{~F}_{2}(\mathrm{aq})\right)$. This trend in $\lambda_{\max }$ for the U(VI)/fluoride complexes differs from the monotonous trend observed for many other complexation systems where higher complexes usually absorb at longer wavelengths [15,17].

\section{(insert Figure 2)}

(insert Figure 3)

The stability constants of the four complexes at $25,40,55$ and $70^{\circ} \mathrm{C}$ have been calculated with the Hyperquad program and shown in Table 1. In the calculation, the protonation constants of fluoride at different temperatures in the literature [17] were used. Data in Table 1 indicate that the complexation of $\mathrm{U}(\mathrm{VI})$ with fluoride is fairly strong and becomes stronger at higher temperatures. When the temperature is increased from $25^{\circ} \mathrm{C}$ to $70^{\circ} \mathrm{C}$, the stability constants of $\mathrm{UO}_{2} \mathrm{~F}^{+}, \mathrm{UO}_{2} \mathrm{~F}_{2}(\mathrm{aq}), \mathrm{UO}_{2} \mathrm{~F}_{3}^{-}$and $\mathrm{UO}_{2} \mathrm{~F}_{4}{ }^{2-}$ are increased by about 2, 3, 8 and 11-fold, respectively. 
The stability constants of $\mathrm{UO}_{2} \mathrm{~F}^{+}, \mathrm{UO}_{2} \mathrm{~F}_{2}(\mathrm{aq}), \mathrm{UO}_{2} \mathrm{~F}_{3}{ }^{-}$and $\mathrm{UO}_{2} \mathrm{~F}_{4}{ }^{2-}$ are plotted as a function of $1 / T$ in Figure 4. The curvature of the plots indicates that the enthalpies of complexation are not constant in the temperature range, and the heat capacities of complexation for the complexes are not zero. This observation could be rationalized by the contributions of the electrostatic interactions between the ionic species and the solvent. In an "isocoulombic" reaction in which the magnitude of the electric charge of each individual ionic species is balanced between the reactants and products, the contributions of electrostatic interactions between the ionic species and the solvent to the temperature dependence of the enthalpy will balance out and the heat capacity of isocoulombic reactions is usually near zero [18]. None of the reactions $1-4$ is isocoulombic. Therefore, it is not surprising that the enthalpies of complexation are not constant and the heat capacities of complexation are not zero.

\section{(insert Figure 4)}

\subsection{Enthalpy and entropy of complexation}

Data of three calorimetric titrations at $25^{\circ} \mathrm{C}$ are shown in Figure 5. The observed reaction heat (total $Q)$ is a function of a number of parameters, including the concentrations of reactants (U(VI), $\mathrm{F}^{-}$and proton), the stability constants and enthalpy of complexation of the $\mathrm{U}(\mathrm{VI}) / \mathrm{F}^{-}$complexes that form in the titration, as well as the protonation constant and enthalpy of protonation of fluoride. Using the stoichiometric concentrations of the reactants, the stability constants of $\mathrm{U}(\mathrm{VI}) /$ fluoride complexes determined by spectrophotometry in this work, and the protonation constant and enthalpy of fluoride previously reported [19], the enthalpies of complexation for $\mathrm{UO}_{2} \mathrm{~F}^{+}, \mathrm{UO}_{2} \mathrm{~F}_{2}(\mathrm{aq}), \mathrm{UO}_{2} \mathrm{~F}_{3}{ }^{-}$and $\mathrm{UO}_{2} \mathrm{~F}_{4}{ }^{2-}$ at $25^{\circ} \mathrm{C}$ are calculated from the calorimetric titration data. The values of enthalpy at $25^{\circ} \mathrm{C}$ from this work are in good agreement with those in the literature $[2,4]$. In conjunction with the stability constants, the entropies of complexation are also calculated (Table 1). 


\section{(insert Figure 5)}

The enthalpy and entropy data in Table 1 indicate that the complexation of $\mathrm{U}(\mathrm{VI})$ with fluoride is slightly endothermic. The positive entropy of complexation is the thermodynamic driving force for the formation of $\mathrm{U}(\mathrm{VI})$ /fluoride complexes. Release of water molecules from the hydration spheres of both $\mathrm{UO}_{2}{ }^{2+}$ and $\mathrm{F}^{-}$to the bulk water contributes to the overall entropy of complexation.

\subsection{Coordination modes}

The results of EXAFS experiments are shown in Figure 6 and Table 2. In Figure 6, the radial distribution plots (FT magnitude vs. $R$ ) of all five solutions show a prominent peak representing two oxygen atoms at $1.76-1.80 \AA$, which can be assigned to the "axial" oxygen in the $\mathrm{UO}_{2}{ }^{2+}$ cation. Beyond this oxygen shell, the features in the radial distribution plots are assigned to coordinating atoms (oxygen and fluorine) in the equatorial plane of the $\mathrm{UO}_{2}{ }^{2+}$ cation. The FT magnitude of Solution I was best-fitted with five oxygen atoms at $2.42 \AA$, suggesting that the dominant species in this solution is $\mathrm{UO}_{2}\left(\mathrm{H}_{2} \mathrm{O}\right)_{5}{ }^{2+}$. For Solutions II - V, the EXAFS data were best-fitted with two equatorial coordination shells: one at $2.26-2.29 \AA$ assigned to the fluoride ion, the other at $2.41-2.52 \AA$ assigned to oxygen atoms from water molecules. For all five samples, the total coordination number (including $\mathrm{O}$ and $\mathrm{F}$ ) in the equatorial plane of $\mathrm{UO}_{2}{ }^{2+}$ remains to be 5. From Solution II to V, the average number of fluoride per uranium increased from 1.2 to 3.8 while the average number of equatorial oxygen per uranium decreased from 4.4 to 1.5 . These results show the successive formation of four $\mathrm{U}(\mathrm{VI}) /$ fluoride complexes: $\mathrm{UO}_{2} \mathrm{~F}^{+}, \mathrm{UO}_{2} \mathrm{~F}_{2}(\mathrm{aq}), \mathrm{UO}_{2} \mathrm{~F}_{3}{ }^{-}$and $\mathrm{UO}_{2} \mathrm{~F}_{4}{ }^{2-}$. As shown in Table 2, the average numbers of fluoride observed by EXAFS are in good agreement with those obtained by speciation calculation using the thermodynamic constants measured by spectrophotometry in the present work.

It should be noted that the only significant deviation between the experimental data and the fits in the EXAFS spectra occurs at about $k=10 \AA^{-1}$ (Figure 6). Such deviation, as pointed out by an anonymous reviewer, could be the result of a $2 \mathrm{p} 4 \mathrm{f}$ double-excitation in the $\mathrm{L}_{3}$ EXAFS spectra of actinides [20] 
which becomes visible due to the damped EXAFS amplitude in this $k$-range. The double-excitation is expected to have some effect on the calculated coordination number, but little effect on the calculated bond distance. We believe that the uncertainties assigned to the coordination numbers $(15 \%-25 \%)$ in this work are sufficiently large to cover the deviations caused by the double-excitation effect.

Data from the present work on the coordination modes of $\mathrm{UO}_{2} \mathrm{~F}_{3}{ }^{-}$and $\mathrm{UO}_{2} \mathrm{~F}_{4}{ }^{2-}$ complexes are in good agreement with the EXAFS data in the literature that have shown the $\mathrm{UO}_{2} \mathrm{~F}_{3}^{-}$and $\mathrm{UO}_{2} \mathrm{~F}_{4}{ }^{2-}$ complexes (identified as $\mathrm{UO}_{2} \mathrm{~F}_{3}\left(\mathrm{H}_{2} \mathrm{O}\right)_{2}{ }^{-}$and $\mathrm{UO}_{2} \mathrm{~F}_{4}\left(\mathrm{H}_{2} \mathrm{O}\right)^{2-}$ ) have pentagonal bipyramid geometry with U-F and U$\mathrm{H}_{2} \mathrm{O}$ distances equal to 2.26 and $2.48 \AA$ [21]. A weak $\mathrm{UO}_{2} \mathrm{~F}_{5}{ }^{3-}$ complex was identified by ${ }^{19} \mathrm{~F}$ NMR $[22,23]$ and the stepwise stability constant $\left(\mathrm{UO}_{2} \mathrm{~F}_{4}{ }^{2-}+\mathrm{F}^{-}=\mathrm{UO}_{2} \mathrm{~F}_{5}{ }^{3-}\right)$ was calculated to be $(0.60 \pm 0.05)$ $\left(\mathrm{mol} \cdot \mathrm{dm}^{-3}\right)^{-1}$ at $25^{\circ} \mathrm{C}$. Obviously such weak complex forms only in very concentrated fluoride solutions. The results of spectrophotometry and EXAFS indicate that the $\mathrm{UO}_{2} \mathrm{~F}_{5}{ }^{3-}$ complex can be neglected under the experimental conditions in the present work.

3.4 Calculation of stability constants at variable temperatures to infinitely dilute solutions: Analysis by the Specific Ion Interaction approach (SIT).

Before using the Specific Ion Interaction (SIT) approach to analyze the data, the stability constants of U(VI)/fluoride complexes in molarity should be converted to the constants in molality using eq. 5 described in the literature [24].

$$
\log K_{\mathrm{m}}=\log K_{\mathrm{M}}+\Sigma_{\mathrm{r}} \nu_{\mathrm{r}} \log \vartheta
$$

where $K_{\mathrm{m}}$ and $K_{\mathrm{M}}$ are the equilibrium constants in molality and molarity, respectively. $\Sigma_{\mathrm{r}} v_{\mathrm{r}}$ is the stoichiometric coefficient of the reaction ( $v_{\mathrm{r}}$ is positive for products and negative for reactants) and is equal to $-i$ for the formation of the $\mathrm{ML}_{\mathrm{i}}$ complex $\left(\mathrm{M}+i \mathrm{~L}=\mathrm{ML}_{\mathrm{i}}\right) . \vartheta$ is the ratio of the values of molality to molarity for the specific ionic medium and varies for different media and concentrations. For $1.0 \mathrm{~mol} \cdot \mathrm{dm}^{-3} \mathrm{NaClO}_{4}, \log \vartheta$ is about 0.02 [24]. 
The SIT approach is originated from the Brpnsted-Guggenheim-Scatchard model [25,26,27] and used to calculate the equilibrium constants at zero ionic strength $[2,3,24]$. For reactions $1-4$, the equilibrium constants at $I=0\left(\log \beta^{0}\right)$ are related to $\log \beta$ at other ionic strengths by the following equation:

$$
\log \beta-\Delta Z^{2} \times D=\log \beta^{0}-\Delta \varepsilon I_{\mathrm{m}}
$$

where $\Delta Z^{2}=\left\{\Sigma\left(Z_{\text {products }}^{2}\right)-\Sigma\left(Z_{\text {reactants })}^{2}\right.\right.$, and equals $-4,-6,-6$ and -4 for reaction $1,2,3$ and 4 , respectively. $D$ is the Debye-Huckel term used in the SIT method and $D=A I_{\mathrm{m}}{ }^{1 / 2} /\left(1+1.5 I_{\mathrm{m}}{ }^{1 / 2}\right), I_{\mathrm{m}}$ is the ionic strength in molality, and $\varepsilon$ is the ion interaction parameter used in the SIT method [2,3,24]. The ion interaction parameters $\left(25^{\circ} \mathrm{C}, \mathrm{kg} \mathrm{mol}^{-1}\right)$ involved in reactions 1-4 include the following: $\varepsilon\left(\mathrm{UO}_{2}{ }^{2+}\right.$, $\left.\mathrm{ClO}_{4}{ }^{-}\right), \varepsilon\left(\mathrm{UO}_{2} \mathrm{~F}^{+}, \mathrm{ClO}_{4}{ }^{-}\right), \varepsilon\left(\mathrm{Na}^{+}, \mathrm{F}^{-}\right), \varepsilon\left(\mathrm{Na}^{+}, \mathrm{UO}_{2} \mathrm{~F}_{3}{ }^{-}\right)$, and $\varepsilon\left(\mathrm{Na}^{+}, \mathrm{UO}_{2} \mathrm{~F}_{4}{ }^{2-}\right)$. The values of $\Delta \varepsilon$ at $25^{\circ} \mathrm{C}$ are $(0.19 \pm 0.06),-(0.50 \pm 0.05),-(0.52 \pm 0.08)$ and $-(0.62 \pm 0.10)$ for reactions $1-4$, respectively [2]. For the calculation of $\log \beta^{0}$ at temperatures other than $25^{\circ} \mathrm{C}$, we have adopted the following approaches: (1) using the values of $A$ at different temperatures tabulated in the literature [24]; and (2) using the value of $\Delta \varepsilon$ at $25^{\circ} \mathrm{C}$ for all temperatures, because the values at other temperatures were not known and the errors thus introduced are probably quite small, since the values of $(\partial \varepsilon / \partial T)_{p}$ are usually $\leq 0.005 \mathrm{~kg} \cdot \mathrm{mol}^{-1} \cdot \mathrm{K}^{-1}$ for temperatures below $200^{\circ} \mathrm{C}[24]$. Besides, the values of $(\partial \varepsilon / \partial T)_{p}$ for the reactants and products may balance out each other so that $\Delta \varepsilon$ for many reactions remains approximately constant up to $100^{\circ} \mathrm{C}$ $[28,29]$. The calculated $\log \beta^{0}$ are summarized in Table 1 (the error limits were obtained by propagation of the uncertainties in the experimental values of $\log K_{\mathrm{M}}$ and the uncertainties in $\Delta \varepsilon$ at $25^{\circ} \mathrm{C}$ ). The values of $\log \beta^{0}$ for all four $\mathrm{U}(\mathrm{VI}) /$ fluoride complexes at $25^{\circ} \mathrm{C}$ are in good agreement with those selected by the NEA review within the error limits [2].

\section{SUMMARY}

Four successive $\mathrm{UO}_{2} \mathrm{~F}_{\mathrm{i}}^{(2-i)^{+}}(i=1,2,3,4)$ complexes have been identified in aqueous solutions in the temperature range of $25-70^{\circ} \mathrm{C}$. The complexation is entropy driven and is enhanced at elevated 
temperatures. The stability constants of $\mathrm{UO}_{2} \mathrm{~F}^{+}, \mathrm{UO}_{2} \mathrm{~F}_{2}(\mathrm{aq}), \mathrm{UO}_{2} \mathrm{~F}_{3}{ }^{-}$and $\mathrm{UO}_{2} \mathrm{~F}_{4}{ }^{2-}$ increase by about 2-, 3, 8- and 11-times, respectively, as the temperature is increased from $25^{\circ} \mathrm{C}$ to $70^{\circ} \mathrm{C}$.

ACKNOWLEDGMENTS. This work was supported by the Director, Office of Science, Office of Basic Energy Science and the Director, OST\&I Program, Office of Civilian Radioactive Waste Management, U. S. Department of Energy, under Contract No. DE-AC02-05CH11231 at Lawrence Berkeley National Laboratory.

\section{REFERENCES}

1. Technical Report prepared for U.S. DOE by Bechtel SAIC Company, LLC, "Technical Basis Document No.7: In-Package Environmental and Waste Form Degradation and Solubility,” Revision 1, July 2004.

2. I. Grenthe, J. Fuger, R. J. M. Konings, R. J. Lemire, A. B. Muller, C. Nguyen-Trung, H. Wanner, "Chemical thermodynamics of uranium”, (Wanner, H., Forest, I., eds.), Amsterdam: Elsevier Science Publishers B.V. (1992).

3. R. Guillaumont, T. Fanghanel, J. Fuger, I. Grenthe, V. Neck, D. A. Palmer, M. H. Rand, “Update on the chemical thermodynamics of uranium, neptunium, plutonium, americium and technetium”, (Mompean, F. J.; Illemassene, M.; Domenech-Orti, C.; Ben Said, K. eds.), Amsterdam: Elsevier B.V. (2003).

4. S. Ahrland, L. Kullberg, Acta Chem. Scand. 25 (1971) 3471.

5. Z. Fazekas, T. Yamamura, H. Tomiyasu, J. Alloys Compd., 271-273 (1998) 756.

6. A. Kirishima, T. Kimura, P. Tochiyama, Z. Yoshida, Radiochim. Acta, 92 (2004) 889.

7. J. Jiang, L. Rao, P. Di Bernardo, P. Zanonato, A. Bismondo, J. Chem. Soc. Dalton Trans. (2002) 1832.

8. G. Gran, Analyst 77 (1952) 661.

9. P. Gans, A. Sabatini, A. Vacca, Talanta 43 (1996) 1739. 
10. P. Zanonato, P. Di Bernardo, A. Bismondo, G. Liu, X. Chen, L. Rao, J. Am. Chem, Soc. 126 (2004) 5515.

11. R. Arnek, Arkiv Kemi 32 (1970) 81.

12. T. Ressler, J. Synchrotron Radiat. 5 (1998) 118.

13. A. L. Ankudinov, B. Ravel, J. J. Rehr, S. D. Conradson, Phys. Rev. B 58 (1998) 7565.

14. T. C. W. Mak, W-H, Yip, Inorg. Chim. Acta 109 (1985) 131.

15. L. Rao, J. Jiang, P. Zanonato, P. Di Bernardo, A. Bismondo, A. Yu. Garnov, Radiochim. Acta 90 (2002) 581.

16. L. Rao, G. Tian, J. Chem. Thermodynamics 40 (2008) 1001.

17. G. Tian, L. Rao, J. Chem. Thermodynamics 41 (2009) 569.

18. I. Puigdomenech, A. V. Plyasunov, J. A. I. Grenthe, Temperature corrections to thermodynamic data and enthalpy calculations, in "Modeling in Aquatic Chemistry", I. Grenthe, I. Puigdomenech, Eds. NEA/OECD, Paris, 1997, Chapt. X.

19. L. Rao, G. Tian, Y. Xia, J. I. Friese, Thermodynamics of neptunium(V) fluoride and sulfate at elevated temperatures, in Proceedings of the $11^{\text {th }}$ International High-Level Radioactive Waste Management Conference (IHLRWM), April 30 - May 4, 2006, Las Vegas, Nevada, pp.374-378.

20. C. Hennig, Phys. Rev. B 75 (2007) 035120.

21. V. Vallet, U. Wahlgren, B. Schimmelpfennig, H. Moll, Z. Szabó, I. Grenthe, Inorg. Chem., 40 (2001) 3516.

22. D. Ferri, F. Salvatore, E. Vasca, J. Glaser, I. Grenthe, Acta Chem. Scand., 47 (1993) 855.

23. V. Vallet, U. Wahlgren, Z. Szabó, I. Grenthe, Inorg. Chem., 41 (2002) 5626.

24. W. Hummel, G. Anderegg, I. Puigdomènech, L. Rao and O. Tochiyama, "Chemical Thermodynamics of Compounds and Complexes of: $U, N p, P u, A m, T c, Z r, N i$ and Se with Selected Organic Ligands", (Mompean, F. J.; Illemassene, M.; Perrone, J. eds.), Amsterdam: Elsevier B.V. (2005). 


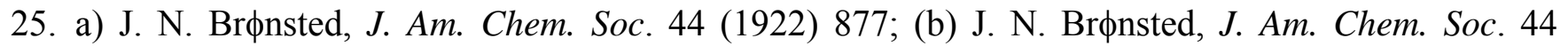
(1922) 938.

26. E. A. Guggenheim, Philos. Mag. 57 (seventh series) (1935) 588.

27. G. Scatchard, Chem. Rev. 19 (1936) 309.

28. A. V. Plyasunov, I. Grenthe, Geochim. Cosmochim. Acta, 58 (1994) 3561.

29. A. Skerencak, P.J. Panak, W. Hauser, V. Neck, R. Klenze, P. Lindqvist-Reis, Th. Fanghänel, "TRLFS study on the complexation of $\mathrm{Cm}(\mathrm{III})$ with nitrate in the temperature range from 5 to $200^{\circ} \mathrm{C}, "$ Radiochim. Acta, in press. 
Table 1. Thermodynamic parameters for the complexation U(VI) with fluoride (sp spectrophotometry, cal - calorimetry, sx - solvent extraction; p.w. - present work). The uncertainties represent $3 \sigma$.

\begin{tabular}{|c|c|c|c|c|c|c|c|}
\hline Reaction & $t^{\circ} \mathrm{C}$ & Method & $\begin{array}{c}\log \beta \\
I=1.0 \\
\mathrm{~mol} \cdot \mathrm{dm}^{-3} \\
\mathrm{Na}\left(\mathrm{ClO}_{4} / \mathrm{F}\right)\end{array}$ & $\begin{array}{l}\log \beta^{0} \\
I=0\end{array}$ & $\begin{array}{c}\Delta H \\
\mathrm{~kJ} \cdot \mathrm{mol}^{-1}\end{array}$ & $\begin{array}{c}\Delta S \\
\mathrm{~J} \cdot \mathrm{K}^{-1} \cdot \mathrm{mol}^{-1}\end{array}$ & Ref \\
\hline \multirow{5}{*}{$\begin{array}{l}\mathrm{UO}_{2}{ }^{2+}+\mathrm{F}^{-}= \\
\mathrm{UO}_{2} \mathrm{~F}^{+}\end{array}$} & 25 & $\mathrm{sp}, \mathrm{cal}$ & $4.60 \pm 0.02$ & $5.20 \pm 0.07$ & $2.8 \pm 0.4$ & $97 \pm 2$ & p.w. \\
\hline & & & & $5.16 \pm 0.06$ & $1.70 \pm 0.08$ & & {$[3,4]$} \\
\hline & 40 & $\mathrm{sp}$ & $4.62 \pm 0.02$ & $5.25 \pm 0.07$ & & & p.w. \\
\hline & 55 & $\mathrm{sp}$ & $4.67 \pm 0.04$ & $5.32 \pm 0.07$ & & & p.w. \\
\hline & 70 & $\mathrm{sp}$ & $4.80 \pm 0.02$ & $5.45 \pm 0.07$ & & & p.w. \\
\hline \multirow{5}{*}{$\begin{array}{l}\mathrm{UO}_{2}{ }^{2+}+2 \mathrm{~F}^{-}= \\
\mathrm{UO}_{2} \mathrm{~F}_{2} \text { (aq) }\end{array}$} & 25 & $\mathrm{sp}, \mathrm{cal}$ & $8.07 \pm 0.04$ & $8.74 \pm 0.07$ & $5.2 \pm 0.8$ & $171 \pm 3$ & p.w. \\
\hline & & & & $8.83 \pm 0.08$ & $2.10 \pm 0.19$ & & {$[3,4]$} \\
\hline & 40 & $\mathrm{sp}$ & $8.21 \pm 0.04$ & $8.91 \pm 0.07$ & & & p.w. \\
\hline & 55 & $\mathrm{sp}$ & $8.32 \pm 0.06$ & $9.06 \pm 0.08$ & & & p.w. \\
\hline & 70 & $\mathrm{sp}$ & $8.52 \pm 0.02$ & $9.31 \pm 0.06$ & & & p.w. \\
\hline \multirow{5}{*}{$\begin{array}{l}\mathrm{UO}_{2}{ }^{2+}+3 \mathrm{~F}^{-}= \\
\mathrm{UO}_{2} \mathrm{~F}_{3}^{-}\end{array}$} & 25 & $\mathrm{sp}, \mathrm{cal}$ & $10.62 \pm 0.04$ & $11.25 \pm 0.09$ & $3.4 \pm 1.1$ & $213 \pm 4$ & p.w. \\
\hline & & & & $10.9 \pm 0.1$ & $2.35 \pm 0.31$ & & {$[3,4]$} \\
\hline & 40 & $\mathrm{sp}$ & $10.78 \pm 0.04$ & $11.44 \pm 0.09$ & & & p.w. \\
\hline & 55 & $\mathrm{sp}$ & $11.21 \pm 0.06$ & $11.91 \pm 0.10$ & & & p.w. \\
\hline & 70 & $\mathrm{sp}$ & $11.55 \pm 0.02$ & $12.29 \pm 0.09$ & & & p.w. \\
\hline \multirow{5}{*}{$\begin{array}{l}\mathrm{UO}_{2}{ }^{2+}+4 \mathrm{~F}^{-}= \\
\mathrm{UO}_{2} \mathrm{~F}_{4}{ }^{2-}\end{array}$} & 25 & $\mathrm{sp}$, cal & $11.92 \pm 0.14$ & $12.01 \pm 0.18$ & $0.2 \pm 3.3$ & $227 \pm 11$ & p.w. \\
\hline & & & & $11.84 \pm 0.11$ & $0.29 \pm 0.47$ & & {$[3,4]$} \\
\hline & 40 & $\mathrm{sp}$ & $12.27 \pm 0.02$ & $12.38 \pm 0.11$ & & & p.w. \\
\hline & 55 & $\mathrm{sp}$ & $12.59 \pm 0.06$ & $12.73 \pm 0.12$ & & & p.w. \\
\hline & 70 & $\mathrm{sp}$ & $12.95 \pm 0.04$ & $13.12 \pm 0.11$ & & & p.w. \\
\hline
\end{tabular}


Table 2. Fitting parameters for uranium L3-edge EXAFS.

\begin{tabular}{|c|c|c|c|c|c|c|c|c|}
\hline \multicolumn{4}{|c|}{ Sample description } & \multicolumn{5}{|c|}{ EXAFS data } \\
\hline \# & $\begin{array}{l}\text { Composition } \\
\left(\mathrm{mol} \cdot \mathrm{dm}^{-3}\right)\end{array}$ & $\begin{array}{l}\text { Dominant } \\
\text { Species }\end{array}$ & $C N(\mathrm{~F})^{\mathrm{a}}$ & Shell & $R,{ }^{\mathrm{b}} \AA$ & $N^{\mathrm{c}}$ & $\sigma^{2},{ }^{\mathrm{d}} \AA^{2}$ & $\Delta E_{0,}, \mathrm{eV}$ \\
\hline \multirow[t]{2}{*}{ I } & $0.045 C_{\mathrm{U}}$ & $\mathrm{UO}_{2}^{2+}$ & 0 & $\mathrm{U}-\mathrm{O}_{\mathrm{ax}}$ & 1.76 & 2.0 & 0.00202 & -12.49 \\
\hline & $0.053 C_{\mathrm{H}}$ & & & $\mathrm{U}-\mathrm{O}_{\mathrm{eq}}$ & 2.42 & 5.1 & 0.00700 & -12.49 \\
\hline \multirow[t]{3}{*}{ II } & $0.045 C_{\mathrm{U}}$ & $\mathrm{UO}_{2} \mathrm{~F}^{+}$ & 1.06 & $\mathrm{U}-\mathrm{O}_{\mathrm{ax}}$ & 1.80 & 2.0 & 0.00229 & -8.19 \\
\hline & $0.053 C_{\mathrm{H}}$ & & & U-F & 2.26 & 1.2 & 0.00080 & -8.19 \\
\hline & $0.050 C_{\mathrm{F}}$ & & & $\mathrm{U}-\mathrm{O}_{\mathrm{eq}}$ & 2.41 & 4.4 & 0.0138 & -8.19 \\
\hline \multirow[t]{3}{*}{ III } & $0.045 C_{\mathrm{U}}$ & $\mathrm{UO}_{2} \mathrm{~F}_{2}(\mathrm{aq})$ & 1.90 & $\mathrm{U}-\mathrm{O}_{\mathrm{ax}}$ & 1.80 & 2.0 & 0.00229 & -9.63 \\
\hline & $0.053 C_{\mathrm{H}}$ & & & U-F & 2.26 & 2.1 & 0.00103 & -9.63 \\
\hline & $0.100 C_{\mathrm{F}}$ & & & $\mathrm{U}-\mathrm{O}_{\mathrm{eq}}$ & 2.43 & 3.2 & 0.00104 & -9.63 \\
\hline \multirow[t]{3}{*}{ IV } & $0.045 C_{\mathrm{U}}$ & $\mathrm{UO}_{2} \mathrm{~F}_{3}^{-}$ & 3.10 & $\mathrm{U}-\mathrm{O}_{\mathrm{ax}}$ & 1.80 & 2.0 & 0.00283 & -10.45 \\
\hline & $0.053 C_{\mathrm{H}}$ & & & U-F & 2.29 & 3.4 & 0.00393 & -10.45 \\
\hline & $0.200 C_{\mathrm{F}}$ & & & $\mathrm{U}-\mathrm{O}_{\mathrm{eq}}$ & 2.50 & 1.8 & 0.00410 & -10.45 \\
\hline \multirow[t]{3}{*}{$\mathrm{V}$} & $0.045 C_{\mathrm{U}}$ & $\mathrm{UO}_{2} \mathrm{~F}_{4}{ }^{2-}$ & 3.90 & $\mathrm{U}-\mathrm{O}_{\mathrm{ax}}$ & 1.79 & 2.0 & 0.00384 & -11.75 \\
\hline & $0.053 C_{\mathrm{H}}$ & & & $\mathrm{U}-\mathrm{F}$ & 2.29 & 3.8 & 0.00499 & -11.75 \\
\hline & $0.670 C_{\mathrm{F}}$ & & & $\mathrm{U}-\mathrm{O}_{\mathrm{eq}}$ & 2.52 & 1.5 & 0.00280 & -11.75 \\
\hline
\end{tabular}

${ }^{a}$ The average coordination number of fluoride per uranium obtained by speciation calculation using the stability constants at $25^{\circ} \mathrm{C}$ from the present work (Table 1).

${ }^{\mathrm{b}}$ The $95 \%$ confidence limits for the bond lengths $(R)$ and coordination numbers $(N)$ for each shell are: $\mathrm{U}-\mathrm{O}_{\mathrm{ax}}, 0.01 \AA$ and $\pm 15 \%, \mathrm{U}-\mathrm{O}_{\mathrm{eq}}, 0.02 \AA$ and $\pm 25 \%$, respectively.

${ }^{c}$ The number of axial oxygen atoms is fixed at 2.0. The amplitude reduction factor $\left(S_{0}{ }^{2}\right)$ is restrained to be 0.9 .

${ }^{\mathrm{d}} \sigma^{2}$ is the EXAFS Debye-Waller term which accounts for the effects of thermal and static disorder through damping of the EXAFS oscillations by the factor $\exp \left(-2 k^{2} \sigma^{2}\right)$. 


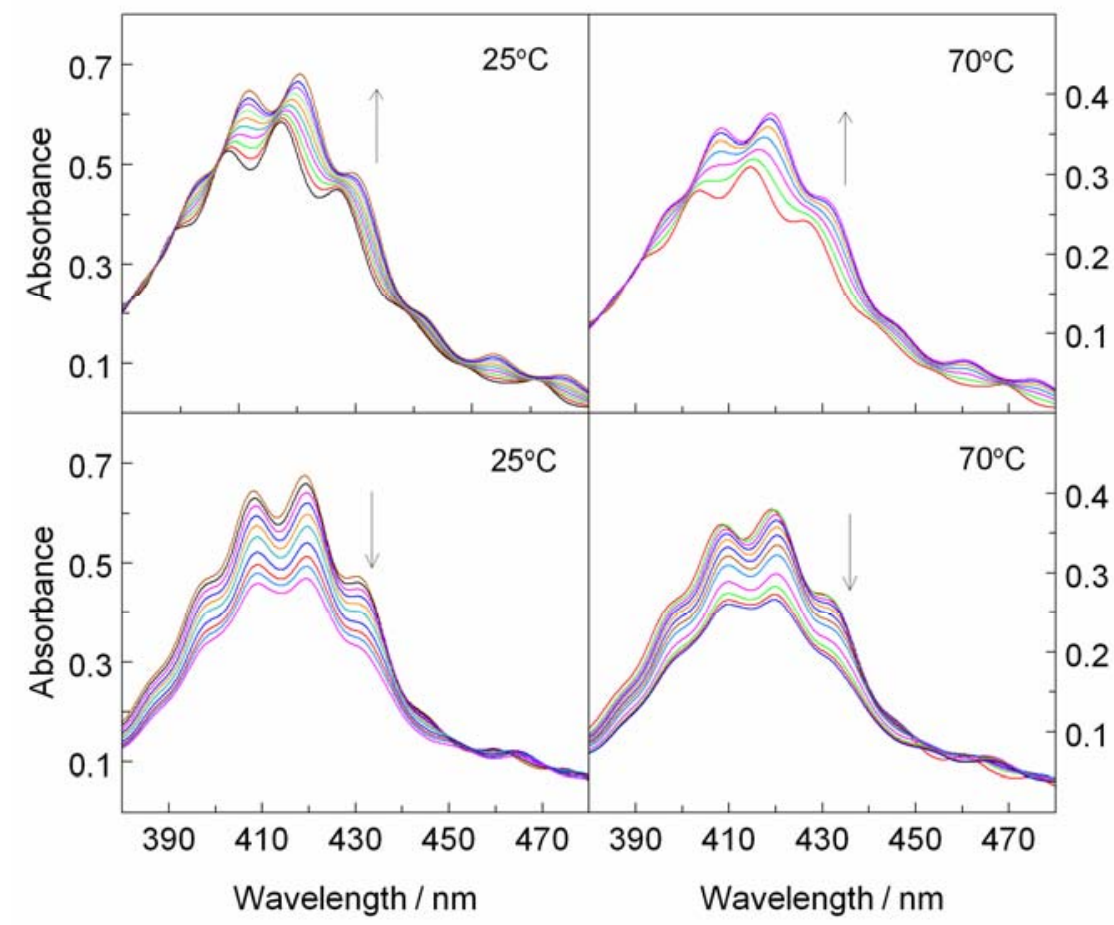

Figure 1. Representative spectrophotometric titrations of U(VI)/fluoride complexation. $I=1.0 \mathrm{~mol} \cdot \mathrm{dm}^{-3}$ $\mathrm{Na}\left(\mathrm{ClO}_{4} / \mathrm{F}\right)$. Upper figures - the first phase of the titrations where the absorbance increased as the concentration of fluoride was increased. Lower figures - the second phase of the titrations where the absorbance decreased as the concentration of fluoride was increased. Cuvette solutions: $V^{0}=2.50 \mathrm{ml}$; left figures $\left(25^{\circ} \mathrm{C}\right), C_{\mathrm{U}}^{0} / C_{\mathrm{H}}{ }^{0}=0.0708 / 0.1242 \mathrm{~mol} \cdot \mathrm{dm}^{-3}$; right figures $\left(70^{\circ} \mathrm{C}\right), C_{\mathrm{U}} / C_{\mathrm{H}}{ }^{0}=0.0354 / 0.08184$ mol $\cdot \mathrm{dm}^{-3}$. Titrant: $C_{\mathrm{F}} / C_{\mathrm{H}}=1.00 / 0.100 \mathrm{~mol} \cdot \mathrm{dm}^{-3}$. The spectra are normalized for the total concentration of $\mathrm{U}(\mathrm{VI})$. The arrows indicate the progress of the titrations. 


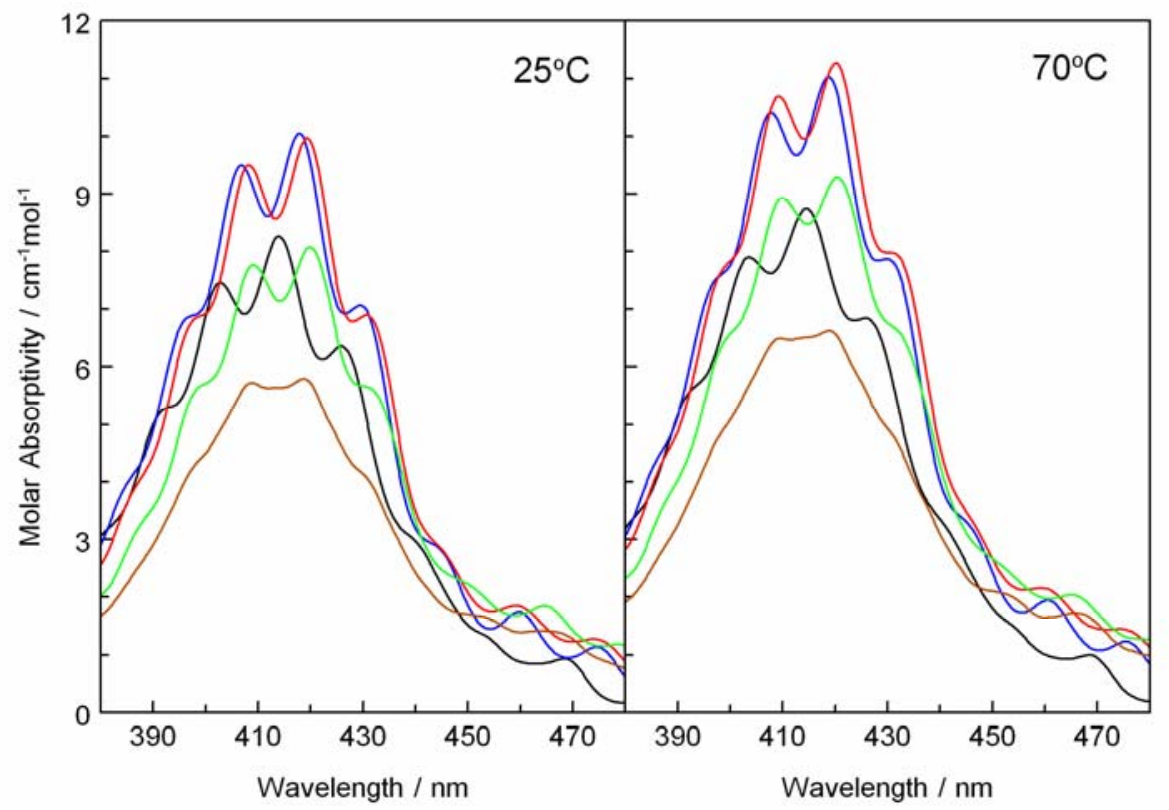

Figure 2. Calculated molar absorptivity of U(VI)/fluoride complexes. $I=1.0 \mathrm{~mol} \cdot \mathrm{dm}^{-3} \mathrm{Na}\left(\mathrm{ClO}_{4} / \mathrm{F}\right)$. Black $-\mathrm{UO}_{2}{ }^{2+}$, blue - $\mathrm{UO}_{2} \mathrm{~F}^{+}$, magenta - $\mathrm{UO}_{2} \mathrm{~F}_{2}(\mathrm{aq})$, green - $\mathrm{UO}_{2} \mathrm{~F}_{3}{ }^{-}$, brown - $\mathrm{UO}_{2} \mathrm{~F}_{4}{ }^{2-}$. 

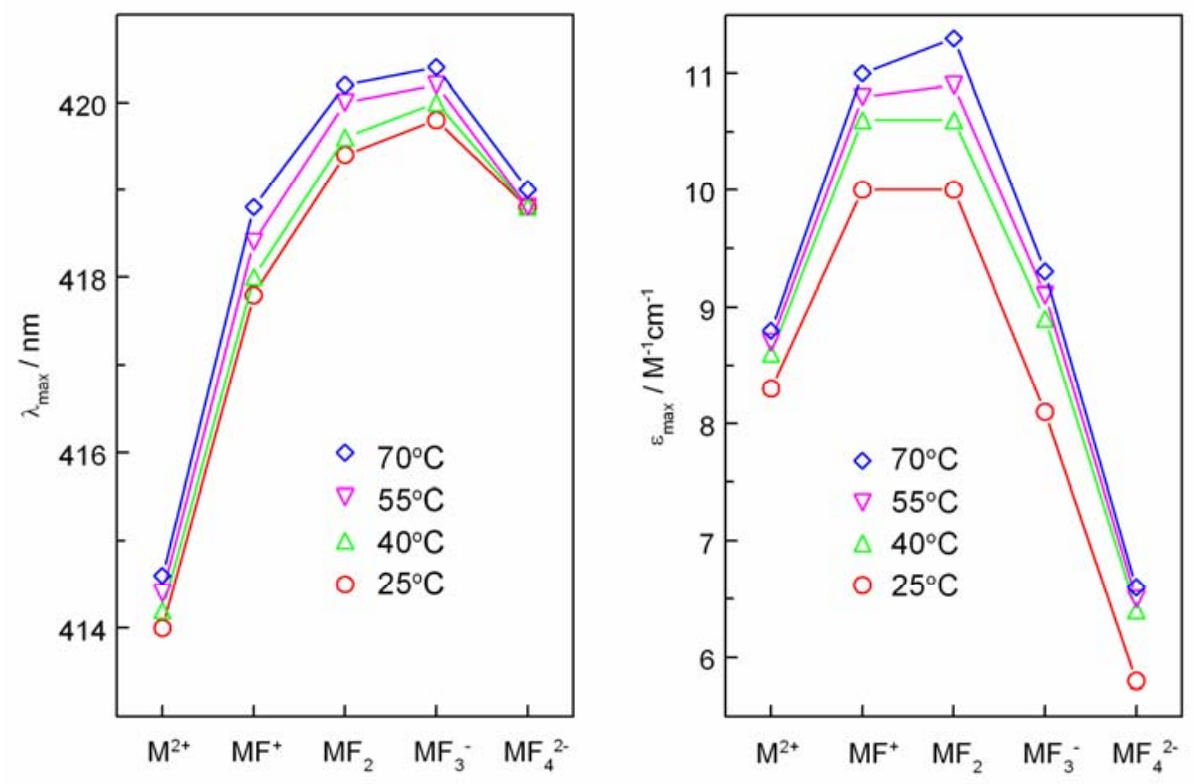

Figure 3. The wavelength for maximum absorption $\left(\lambda_{\max }\right)$ and the molar absorptivity at $\lambda_{\max }\left(\varepsilon_{\max }\right)$ for the $\mathrm{U}(\mathrm{VI})$ species. $\mathrm{M}^{2+}, \mathrm{MF}^{+}, \mathrm{MF}_{2}, \mathrm{MF}_{3}^{-}$and $\mathrm{MF}_{4}{ }^{2-}$ stands for $\mathrm{UO}_{2}{ }^{2+}, \mathrm{UO}_{2} \mathrm{~F}^{+}, \mathrm{UO}_{2} \mathrm{~F}_{2}, \mathrm{UO}_{2} \mathrm{~F}_{3}{ }^{-}$and $\mathrm{UO}_{2} \mathrm{~F}_{4}{ }^{2-}$. 


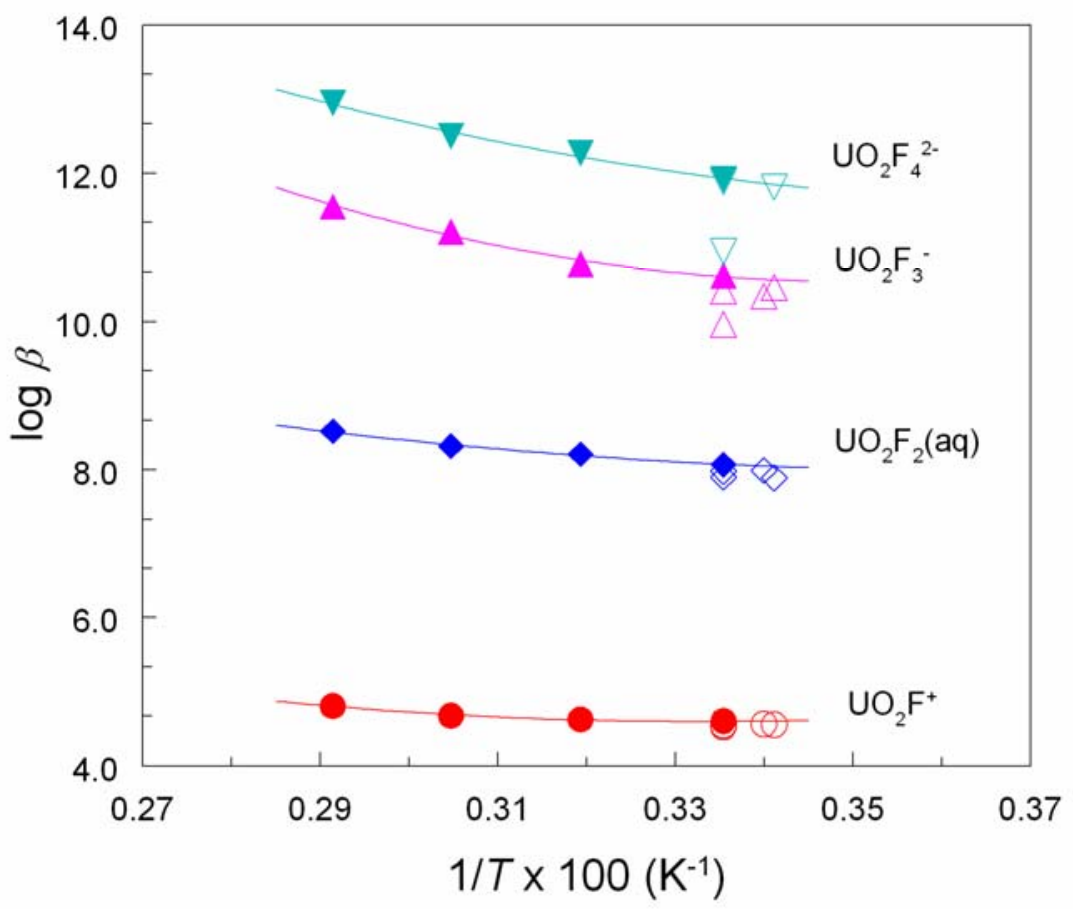

Figure 4. $\log \beta$ vs. $1 / T$ for the complexation of $\mathrm{U}(\mathrm{VI})$ with fluoride. $I=1.0 \mathrm{~mol} \cdot \mathrm{dm}^{-3} \mathrm{Na}\left(\mathrm{ClO}_{4} / \mathrm{F}\right)$. Solid symbols: data from this work; open symbols: data at $I=1.0 \mathrm{~mol} \cdot \mathrm{dm}^{-3} \mathrm{NaClO}_{4}$ from the literature [3]. 

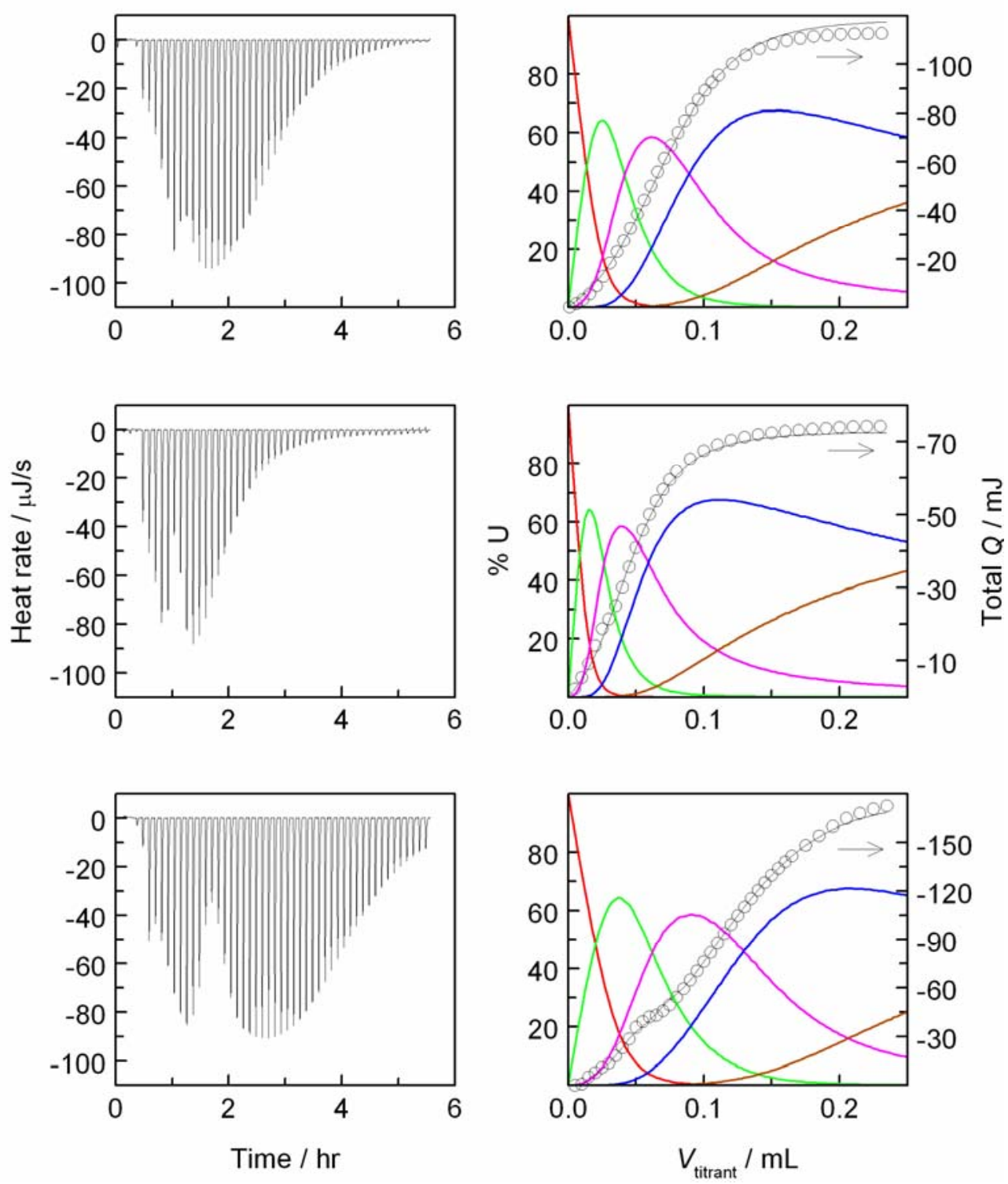

Figure 5. Calorimetric titration of $\mathrm{U}(\mathrm{VI})$ fluoride complexation. $I=1.0 \mathrm{~mol} \cdot \mathrm{dm}^{-3} \mathrm{Na}\left(\mathrm{ClO}_{4} / \mathrm{F}\right), t=25^{\circ} \mathrm{C}$. Left column: thermograms of the titrations; right column: total heat $(\bigcirc-\exp ,-$ cal $)$ and the speciation of $\mathrm{U}(\mathrm{VI})$ (red $-\mathrm{UO}_{2}{ }^{2+}$, green $-\mathrm{UO}_{2} \mathrm{~F}^{+}$, magenta $-\mathrm{UO}_{2} \mathrm{~F}_{2}(\mathrm{aq})$, blue $-\mathrm{UO}_{2} \mathrm{~F}_{3}$, brown $-\mathrm{UO}_{2} \mathrm{~F}_{4}{ }^{2-}$ ) as a function of the titrant volume. Cup solutions: $0.900 \mathrm{~mL}, C_{\mathrm{U}} / C_{\mathrm{H}}\left(\mathrm{mmol} \cdot \mathrm{dm}^{-3}\right)=7.87 / 9.80$ (top), 4.92/6.10 (center), 11.80/14.70 (bottom). Titrant: $C_{\mathrm{F}} / C_{\mathrm{H}}\left(\mathrm{mmol} \cdot \mathrm{dm}^{-3}\right)=300 / 33.3,5 \mu \mathrm{L} /$ addition. 

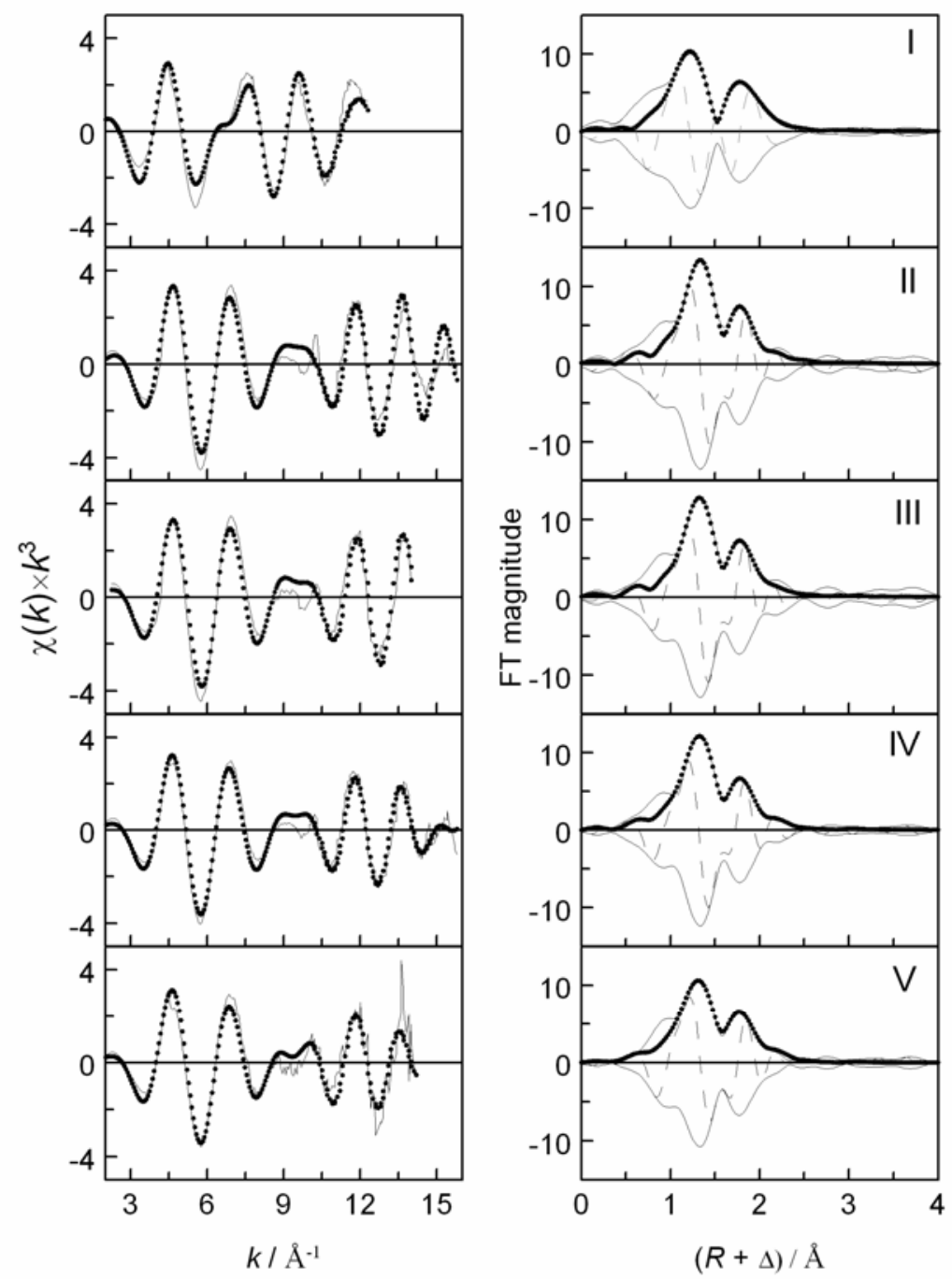

Figure 6. EXAFS spectra (left) and FT magnitude (right) for U(VI)/Fluoride systems (Solutions I - V, t $=22^{\circ} \mathrm{C}$ ). Solid Lines - experimental; Dotted lines - fitted. 


\section{SYNOPSIS}

Complexation of $\mathrm{UO}_{2}{ }^{2+}$ with fluoride in aqueous solutions is entropy driven and is enhanced at elevated temperatures.

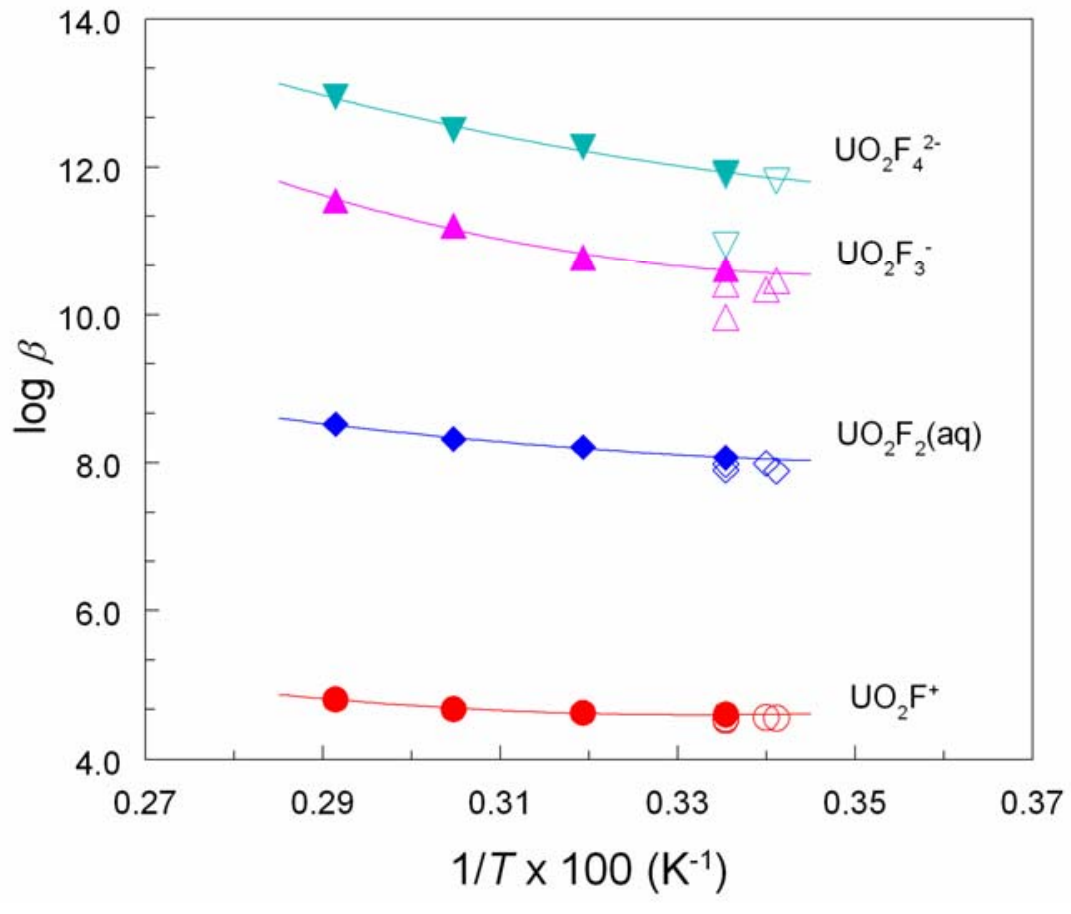

